\section{Dale Jamieson}

\author{
University of Colorado
}

In "Rational Egoism, Animal Rights, and the Academic Connection" (Between the Species I/2 (1985), pp. 21-7), Dr. George Cave replies to an article of mine that appeared in a philosophical journal in 1981 ("Rational Egoism and Animal Rights," Environmental Ethics 3 (1981), pp. 167-71). In the course of Dr. Cave's reply--the second which he has published in response to my rather modest article (the first being a review in Ethics \& Animals 2 (1981), pp. 61-3)--he accuses me of "extreme quibbling," says that my arguments are "thoroughly speciesist," and claims that some of my proposed counter-examples "[resenble] the paranoid speculations which underlie the domino theory in politics. Dr. Cave's conclusion is that "it is morally repugnant to see philosophers engaging in gratuitous debates on highly technical and pragmatically irrelevant aspects of the moral issue of animal rights, or sowing the seeds of doubt concerning the justifiability of human treatment of non-human animals for no other reason than idle curiosity." Such pernicious behavior, of which, presumably, I am an exemplar, "serves only to drain liberation movements of their life-blood, and if not actually immoral, [is] at least utterly devoid of all redeeming moral conviction."

Much of this is simply hot air and not worth taking seriously. Some of it is bad faith. Who else would publish two replies to an "extremely quibbling" article but someone with a Ph.D.? Still, reflecting upon Dr. Cave's article can teach us something.

The charge that my arguments are "incorrigibly speciesist" is reminiscent of the ultra-leftism which took such a toll on the movements of the 1960 's. Then, as now, th: enemy was always within. Nothing is more destructive of a radical movement for social change than this kind of divisive, ill-tempered bickering.

What seems to bother Dr. Cave is that my article was an "internal" reply to a critic of animal rights. I tried to grant the critic (Jan Narveson) as much as possible and to

show that even so, his argument fails. Such a strategy, if successful, can be devastating. At the time my article was written, 1977, the animal rights view was not wellestablished within the philosophical communi-

BETWEEN THE SPECIES ty. Narveson was the first influential philosopher to reply to Regan and Singer. I thought it important to show that Narveson's critique of animal rights failed even in its own terms. Whether or not my reading of the philosophical landscape was correct and whether or not my arguments were successful are questions that can be debated. But it is churlish in the extreme to fault me for even attempting such a refutation of Narveson.

Dr. Cave is concerned about "the danger of enervation faced by any liberation movement when its issues become the focus of debate within the academic context." I am sympathetic to Dr. Cave's concern. But the danger of "enervation" comes not from the attention that academic philosophers have focused on the question of animal rights but, rather, from the twin temptations of "careerism" and opportunism.

Academic philosophy and the animal liberation movement have both benefited greatly from their close connection. As a result of its confrontation with the question of animal rights, academic philosophy has become more sensitive to the real world and more open in its concerns (though it has a long way to go). From the involvement of philosophers, the movement has gained intellectual breadth and respectability. It has also gained many committed activists. Still, philosophers are no better than anyone else, and I have no doubt that some have been attracted to animal rights as a way of getting a job or of building a career. Some activists have undoubtedly been attracted to the movement for similar reasons. People get addicted to running organizations, having followers, seeing their name in print, and so forth. It is important to get people into the movement however we can. Still, in the long run, such careerism and opportunism can be "enervating." The only real defense against them is for all of us to try to keep our own motivations in as clear a view as possible. Our common goal is justice for the animals, not attention for ourselves. Sometimes we forget this in our desire to set others straight.

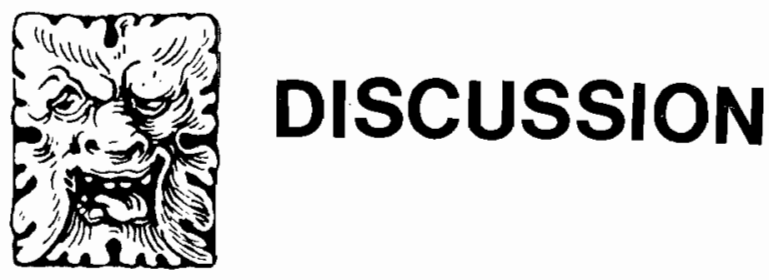

